\title{
Socioemotional predictors of motivation for abstinence in alcohol addicts
}

\author{
Darija Šarić ${ }^{1}$, Anamarija Bogović Dijakovićc, \\ ${ }^{1}$ Catholic University of Croatia, Zagreb, Croatia, ${ }^{2}$ Department of Psychiatry, University \\ Hospital Center Sestre milosrdnice, Zagreb, Croatia
}

\begin{abstract}
Motivation for abstinence is one of the most significant predictors of the patient's treatment engagement and completion, as well as the treatment outcome. Since this complex process has not been sufficiently studied, in clinical practice the need for a better understanding and perception of it has arisen, namely due to its significant contribution to hospital care programs. The aim of this study was to identify the socio-emotional predictors of motivation for abstinence in patients undergoing treatment for a minimum of 12 days. The study involved 72 volontary participants from Department of Alcohol Program in one psychiatric hospital. Motivation for abstinence was studied using the SOCRATES questionnaire which, along with the subscales of ambivalence, recognition and taking steps, represents a criterion. Demographic variables, emotional regulation and control, instrumental and emotional support seeking, life satisfaction, positive and negative emotions and flourishing were examined as potential predictors. Regression analysis showed that emotional regulation and control and instrumental and emotional support seeking significantly explain $15.8 \%$ of ambivalence, $29.4 \%$ of recognition and $30.6 \%$ of taking steps; life satisfaction, positive and negative emotions significantly explained $11.3 \%$ of taking steps, while flourishing accounted for $13.7 \%$ of taking steps. As for the demographic variables, only sex, age and education level acounted for $15.6 \%$ of recognition. In spite of the result obtained, the overall percentage of the explained variance is relatively low. Clinical implications of this study are significant and their greatest contribution is maximizing hospital care programs pertaining to rehabilitation of alcoholics.
\end{abstract}

Key words: motivation, abstinence, addiction, alcoholism, emotions

Copyright @ 2018 KBCSM, Zagreb

e-mail: alcoholism.kbcsm@gmail.com•www.http://apr.kbcsm.hr

\section{Introduction}

Alcohol addiction is a chronic disease that represents one of the biggest social problems and is spreading fast. DSM-V classification defines alcohol addiction as

Correspondence to author: Daria Šarić Davorina Bazjanca 17, 10000 Zagreb

Telephone: 091/2150493;

E-mail address: daria.saric7@gmail.com a set of behavioral and physical symptoms that are present in specific time period and that can include withdrawal symptoms, tolerance and craving, which leads to significant clinical damage [1]. Nowadays, alcohol abuse disorder is the third leading problem in public health and fourth leading cause of death, from which 2.5 million people die every year [2]. 
Alcohol addiction is a disease that develops progressively and it is usually not detected for a long time. There are various reasons why people with alcohol related problems do not enter treatment and some of the variables that affect those kind of decisions are employment, education, perceived problem severity, public health support and cognitive functioning [3,4]. Treatment selection is a long-term process that is affected by factors such as problem denial and shortage of support, resources and ability that are needed for cognitive and behavioral change.

Some studies show that longer staying in treatment is associated with stabilization and improvement of protective factors that affect long-term effects of treatment and longer remission [5]. This is in accordance with findings which suggest that an earlier checkout from hospital treatment and quitting the treatment are equally important as is the relapse [6]. Taking this into consideration, scientists have started to study specific reasons that lead to treatment failure or patient leaving the treatment and have found that one of the most common reasons for leaving the treatment is the lack of motivation.

Motivational constructs are the key elements in many theoretical approaches to addiction and are strong predictors of behavioral change that is connected to alcohol consumption [7]. Stage of motivation defines inclusion of persons with alcohol addiction in treatment, their retention and outcome of treatment and it is found that bigger motivation for change predicts a decrease in consumption of harmful substances [8]. Respectively, motivation for abstinence includes a real desire to quit alcohol consumption, a need for changing addictive behavior and active search for help to achieve the change [9].
Some theoretical concepts of motivation led to new scientific approaches that resulted in several motivational models with focus on stages of change. One of the models was developed by Miller and Tonigan who stated that motivation to change alcohol related behavior has three stages $[10,11]$. First stage is ambivalence in which a person is not completely certain if change of alcohol addictive behavior is needed. Ambivalence is followed by the second stage, recognition, in which a person becomes more aware of alcohol related problems. The last stage is taking steps in which a person is actively changing their own behavior [10].

Identification of relationship between motivation for change and positive outcome is very important for the purpose of understanding the managment of alcohol addiction treatment. Results of previous studies suggest that bigger commitment to abstinence leads to various positive outcomes in patients' recovery, which is primarily visible in a greater number of patients who finished the entire treatment $[12,13]$.

Early abstinence from alcohol is connected with changes in reward system. Latest studies show that brain regions included in reward system are also connected with emotional regulation and control [14].

Emotional regulation and control refers to experience controlling and emotion expression during stressful events by dint of strategies such as repression and cognitive restructuring [14]. Understanding the way in which alcohol addicts identify their emotions and accept them, their ability to control impulsive behavior and ability to find emotional regulation strategies would help in longterm abstinence. A few studies have found that emotional expressiveness is one of the most important psychological factors, which 
is significantly connected with readiness for a change in alcohol addicts [15]. Respectively, those alcohol addicts who have better regulation of their emotions later show higher motivation for abstinence, while people who are impulsive and receptive, with poor emotional control later show greater rates of relapse and lower motivation to change addictive behavior $[15,16]$.

Despite these results, the relationship between emotional regulation, control and readiness to change addictive behavior is still not clearly defined.

The role of negative emotions in alcohol addicts is well studied while new studies have been made to investigate the relationship between positive emotions and motivation for abstinence of alcohol. Presence of aversive affect, for example anxiety, can be a trigger for repetition of addictive beahvior. Some results showed that the presence of dominant negative emotional events is related to a greater risk of relapse after completion of detox program [17,16]. Negative emotional events can also affect desire to change addictive behavior and decrease self-confidence for dealing with stress after abstinence is reached [18].

Thus, Fredrickson [19] suggests extended model that includes negative and positive emotions, which mainly encourages cognitive and later physical change. Positive effect model represents the fact that openness to new experiences and active search of own resources encourage desired change of negative behavior [16]. Despite that, the relationship between emotional and motivational state within alcohol addicts is still not well clarified.

Furthermore, coping strategies are also important factors in understanding the way in which people deal with stressful life situations. Unlike avoidance coping, that at the same time is the most investigated coping style, coping that includes positive approach in dealing with stress in proactive coping. Proactive coping is a multidimensional type of coping that is oriented in future. Motivation in proactive coping is positive because situation is perceived as stimulating and challenging. Greenglass [20], suggests that social support as a coping type has several important functions that are identified as instrumental and emotional support that are helping a person to change a perception of stressful situation aspects.

Instrumental support refers to obtaining advice, information and feedback from others while emotional support focuses on regulation and control of temporary emotional distress with the help of people in one own's social network [21]. Proactive coping style and its instrumental and emotional seeking strategies are not studied in alohol addicts and neither is the motivation in the context of abstinence [22].

Alcohol addiction has consequences at individual's health, but also at their own life satisfaction. Considering that there is still no consensus with life satisfaction definition, there are three components of life satisfaction that are accepted universally: physical, social and mental health and functioning. Previous research that included life satisfaction shows that it is pretty low in alcohol addicts and in those people who are currently looking for help. This result is constant in comparative studies with control groups $[23,12]$. Relationship between alcohol addiction and life satisfaction is two-way and complex which demands more studies to clarify that relationship. 
Closely related to life satisfaction is the flourishing that refers to positive functioning, emotional stability and personal, social and health benefits [24,25]. Flourishing also refers to a spiritual presence in all aspects of individual's life, such as meaning of life, self efficacy and desire to achieve a better life. Flourishing can assure the understanding of life context which is of great relevance for a successful coping in difficult situations. Despite that, flourishing is a new dimension of subjective wellbeing and is poorly present in motivation for abstinence studies.

Significance of sociodemographic factors in cognitive and emotional functioning of an alcohol addict and in motivation for abstinence has been found in many studies. Generally, it has been found that risk factors for negative outcomes in addiction treatment are male gender, younger age, unemployment, low education and divorce or never married individuals [26-28, 7]. Howewer, results are inconsistent.

Given the key role of motivation in achieving and maintainig alcohol abstinence, it has become important, both theoretically and clinically, to identify the factors that encourage dedication to abstinence, and especially those factors that can be changed. In previous studies motivational constructs have been usually used as predictors and so far only few studies have studied factors that affect motivation for abstinence. These studies' contributions for clinical practice would be significant and could develop and improve interventions and therapies that would focus on emotional aspects of functioning. Therefore, the aim of this study was to investigate how much of variance of motivation for abstinence can be explained by gender, age, education level, marital status, type of hospitalization, emotional regulation and control, instrumental and emotional support seeking, life satisfaction, positive and negative emotions and flourishing. It is hypothesed that gender, age, education level and flourishing will not be significant predictors of ambivalence, recognition and taking steps while marital status, type of hospitalization, emotional regulation and control, instrumental and emotional support seeking, life satisfaction, positive and negative emotions will significantly contribute to explanation of ambivalence, recognition and taking steps.

\section{Subjects and methods}

Subjects included 72 voluntary inpatients who were treated for alcohol addiction in one psychiatric hospital in Zagreb, of which 63 were male and 9 were female aging from 29 to 74 years $(M=49.13$; $S D=10.96)$. Inclusion criteria for this study were that inpatients were in hospital treatment for at least 12 days. Average days spent in hospital treatment of those inpatients who filled this criteria was 40 days $(M=40.44$; $S D=36.28)$, with minimum of 12 days and maximum of 80 days. Participants in this study on average had 7 hospitalizations $(M=7.58 ; S D=14.38)$ with average duration of all previous treatment of 13 months $(M=13.75 ; S D=23.09)$. In this sample, $63.9 \%$ of participants were voluntary impatiens and $36.1 \%$ came at the consent of family, friends, courts or police. Participants mostly have high school education and are married or in a relationship.

\section{Measures}

Questionnaire especially constructed for this study was used for collecting sociodemographic data

Motivation for abstinence. Motivation for abstinence was assessed with The 
Stages of Change Readiness and Treatment Eagerness Scale [10] that measures the ability of an alcohol addict to change. The SOCRATES is a 19-item self -- report instrument that utilizes a 5 point Likert - type scale (1 - strongly disagree to 5 - strongly agree). The instrument yields three scale scores: recognition, ambivalence and taking steps. In previous studies these scales displayed good internal consistencies with Cronbach's Alpha being 0.88 for recognition, 0.95 for ambivalence and 0.96 for taking steps [10]. In this study psychometric analyses revealed following Cronbach's Alpha, 0.78 for recognition, 0.68 for ambivalence and 0.80 for taking steps.

Emotional regulation and control. Emotional regulation and control was assessed with the Emotional regulation and control questionnaire [29] that consisted of 20 items focusing on impacts of negative emotions on memory, thinking and behavior. Items were rated on a 5 point Likert - type scale (1- not at all to 5 - completely). The ERIK total score showed good internal consistency in previous studies with Cronbach's Alpha $=0.89$ [29] and that was also confirmed in this study with Cronbach's Alpha $=0.91$.

Instrumental support seeking. Instrumental support seeking scale is a part of The Proactive Coping Inventory [30]. It has 8 items which are focused on obtaining advice and feedback from other people when dealing with stressful situations. Is uses 5 point Likert - type scale from 1 (completely false) to 4 (completely true) and has good reliability with Cronbach's Alpha $=0.85$ [31]. Cronbach's Alpha in this study was 0.86 .

Emotional support seeking. Emotional support seeking is 5 -item scale that is also a part of The Proactive Coping Inventory [30] and is aiming regulation of temporary emotional distress that is manifested threw evoking empathy. Is uses 5 point Likert - type scale from 1 (completely false) to 4 (completely true) and has also good reliability with Cronbach's Alpha $=0.75$ [30]. Cronbach's Alpha in this study was 0.77 .

Life satisfaction. Life satisfaction is measured with Satisfaction with Life Scale [31] that consists of 5 items that focuses on general cognitive assessment of satisfaction with life. It uses 7 - point Likert -type scale (1 - strongly disagree to 7 - completely agree). Cronbach's Alpha in previous studies was 0.87, and in this study was 0.69 .

Positive and negative emotions. Positive and negative emotions were assessed with Scale of Positive and Negative Experience [32] that has 6 items that measure positive and 6 items that measure negative emotions in last 2 weeks. This instrument utilizes 5 - point Likert - type scale $(1$ - not at all to 5 - very much) and yields 2 scores, 1 for negative and 1 for positive experiences. In previous studies Cronbach's Alpha for positive experiences was 0.89 and for negative experiences 0.84 while in this study was 0.88 for positive experiences and 0.85 for negative experiences [33].

Flourishing Flourishing is assessed with Flourishing Scale [32], an 8 - item scale that focuses on important aspects of human functioning as positive social relations, feeling of competence and ability in activities that are important for individuals. Answers were rated on a 7 - point Likert - type scale (1 - strongly disagree to 7 - completely agree). Instrument displayed good internal consistency with Cronbach's Alpha $=0.89$ in previous studies and is confirmed in this study (Cronbach's Alpha $=0.83$ ) [33]. 


\section{Procedure}

Prior to conducting the study ethical approval was granted. Subjects were given the informed consents and were guaranteed anonymity of data.

\section{Results}

Prior to starting the analysis, normality of distribution was tested with KolmogorovSmirnov test. Obtained values and other descriptive data are showed in Table 1.

The analysis showed that result distributions significantly deviate from recognition and ambivalence scale therefore the analysis of skewnes and kurtosis was conducted. The result showed that that skewnes index was $-1.234(\mathrm{SD}=0.28)$ and kurtosis index was .901 ( $\mathrm{SD}=0.56)$ for recognition scale, while for ambivalence scale skewnes index was $-1.051(\mathrm{SD}=0.28)$ and kurtosis index was .611 ( $\mathrm{SD}=0.56)$ which indicates that in further analysis is justifiable to use parametric statistics.

Several regression analyses with ambivalence, recognition and taking steps as criteria variables were run in order to give an answer to the problem of this study. Due to a small sample and preconditions, predictors were organized in 4 multiple and 1 linear regression analysis. All results obtained are shown in Table 2.

First regression analysis showed that marital status and type of hospitalization are not significant predictors of ambivalence, recognition and taking steps.

Table 1. Values of Kolmogorov-Smirnov test for normality of distribution and descriptive parameters of used variables on a sample of 72 participants

\begin{tabular}{lcccccc}
\hline & Kolmogorov $Z$ & $M$ & $S D$ & min & max & $\begin{array}{c}\text { Mogući raspon } \\
\text { rezultata }\end{array}$ \\
\hline Ambivalence & $0.030^{* *}$ & 12.08 & 2.77 & 3 & 15 & $3-15$ \\
Recognition & $0.036^{* *}$ & 26.18 & 3.95 & 15 & 30 & $6-30$ \\
Taking steps & 0.163 & 33.83 & 5.52 & 14 & 40 & $8-40$ \\
Emotional regulation and control & 0.507 & 57.63 & 13.1 & 28 & 93 & $20-100$ \\
Instrumental support seeking & 0.703 & 24.58 & 5.06 & 12 & 32 & $8-32$ \\
& & & & & & \\
Emotional support seeking & 0.125 & 14.50 & 3.57 & 5 & 20 & $5-20$ \\
& & & & & & $5-25$ \\
Positive experiences & 0.125 & 20.93 & 4.8 & 7 & 30 & $6-30$ \\
Negative experiences & 0.367 & 14.36 & 5.05 & 6 & 27 & $5-35$ \\
Satisfaction with life & 0.975 & 18.72 & 5.57 & 15 & 34 & $8-56$ \\
Flourishing & 0.986 & 40.6 & 7.66 & 7 & 56 & \\
\hline
\end{tabular}

Note. Kolmogorov $-Z=$ values given by Kolmogorov-Smirnov test for normality of distribution $M=$ mean values; $S D=$ standard deviation; $\min =$ minimal value; $\max =$ maximum value; ${ }^{*} \mathrm{p}<.05 ;{ }^{*} \mathrm{p}<.01$ 
Table 2. Results of all regression analysis with recognition, ambivalence and taking steps as criteria variables $(\mathrm{N}=72)$

\begin{tabular}{|c|c|c|c|c|c|c|}
\hline \multirow[b]{2}{*}{ Predictors } & \multicolumn{2}{|c|}{ Recognition } & \multicolumn{2}{|c|}{ Ambivalence } & \multicolumn{2}{|c|}{ Taking steps } \\
\hline & $\beta$ & $s r^{2}$ & $\beta$ & $s r^{2}$ & $\beta$ & $s r^{2}$ \\
\hline Marital status & 0.12 & 0.01 & -0.14 & 0.02 & 0.02 & 0 \\
\hline \multirow[t]{3}{*}{ Type of hospitalization } & 0.06 & 0.36 & 0.02 & 0 & 0.03 & 0 \\
\hline & \multicolumn{2}{|c|}{$R^{2}=0.016$} & \multicolumn{2}{|c|}{$R^{2}=0.020$} & \multicolumn{2}{|c|}{$R^{2}=0.001$} \\
\hline & \multicolumn{2}{|c|}{$F(2.69)=0.543$} & \multicolumn{2}{|c|}{$F(2.69)=0.7099$} & \multicolumn{2}{|c|}{$F(2.69)=0.042$} \\
\hline Gender & -0.15 & 0.02 & 0.15 & 0.02 & 0.02 & 0 \\
\hline Age & $-0.39 * *$ & $0.14^{* *}$ & 0 & 0 & -0.24 & 0.1 \\
\hline \multirow{3}{*}{ Education level } & -0.02 & 0 & -0.1 & 0.02 & -0.03 & 0 \\
\hline & \multicolumn{2}{|c|}{$R^{2}=0.156$} & \multicolumn{2}{|c|}{$R^{2}=0.043$} & \multicolumn{2}{|c|}{$R^{2}=0.067$} \\
\hline & \multicolumn{2}{|c|}{$F(3.68)=4.183^{* *}$} & \multicolumn{2}{|c|}{$F(3.68)=1.019$} & \multicolumn{2}{|c|}{$F(3.68)=1.628$} \\
\hline Emotional regulation and control & $0.52 *$ & $0.24 *$ & $0.26^{*}$ & $0.06^{*}$ & 0.15 & 0 \\
\hline Instrumental support seeking & -0.18 & 0.02 & 0.03 & 0 & $0.46^{* * *}$ & $0.12^{* * *}$ \\
\hline \multirow[t]{3}{*}{ Emotional support seeking } & $0.38^{*}$ & $0.08^{*}$ & 0.29 & 0.05 & 0.06 & 0 \\
\hline & \multicolumn{2}{|c|}{$R^{2}=0.294$} & \multicolumn{2}{|c|}{$R^{2}=0.158$} & \multicolumn{2}{|c|}{$R^{2}=0.306$} \\
\hline & \multicolumn{2}{|c|}{$\begin{array}{c}F(3.67)=9.305^{* *} \\
p<0.001\end{array}$} & \multicolumn{2}{|c|}{$F(3.67)=4.190^{* *}$} & \multicolumn{2}{|c|}{$\begin{array}{c}F(3.67)=9.842^{* *} ; \\
p<0.001\end{array}$} \\
\hline Satisfaction with life & 0.03 & 0 & -0.17 & 0.02 & -0.02 & 0 \\
\hline Positive experiences & 0.2 & 0.03 & $0.27 *$ & $0.06^{*}$ & $0.29 *$ & $0.07 *$ \\
\hline \multirow[t]{3}{*}{ Negative experiences } & $0.29 *$ & $0.07 *$ & 0.07 & 0 & 0.04 & 0 \\
\hline & \multicolumn{2}{|c|}{$R^{2}=0.069$} & \multicolumn{2}{|c|}{$R^{2}=0.045$} & \multicolumn{2}{|c|}{$R^{2}=0.113^{*}$} \\
\hline & \multicolumn{2}{|c|}{$F(3.68)=1.673$} & \multicolumn{2}{|c|}{$F(3.68)=1.060$} & \multicolumn{2}{|c|}{$F(3.68)=2.895^{*}$} \\
\hline \multirow[t]{3}{*}{ Flourishing } & \multicolumn{2}{|c|}{0.16} & -0.05 & & 0.37 & \\
\hline & $R^{2}=$ & .027 & $R^{2}=$ & 002 & $R^{2}=$ & .137 \\
\hline & $F(1.69)$ & $=1.902$ & $F(1.69)$ & 0.165 & $\begin{array}{r}\mathrm{F}(1.69)= \\
p<0\end{array}$ & $\begin{array}{l}10.967^{* *} \text {; } \\
001\end{array}$ \\
\hline
\end{tabular}

Note. $\beta=$ standardized beta coefficient; $s r^{2}=$ squared semi - partial correlation; $\mathrm{R}^{2}=$ multiple determination coefficient; $F=$ F value; ${ }^{*} \mathrm{p}<.05 ;{ }^{*} \mathrm{p}<.01$

Second regression analysis showed that gender, age and education level significantly explained $15.6 \%$ variance of recognition $(\mathrm{F}(3.68)=4.183 ; \mathrm{p}=0.009)$, whereby age showed to be the only significant variable that alone explains $14 \%$ variance of recognition.
In third regression analysis significantly was explained $15.8 \%$ variance of ambivalence $(\mathrm{F}(3.67)=4.190 ; \mathrm{p}=0.009)$, whereby only significant predictor was emotional regulation and control that singly explained $6 \%$ variance of ambivalence. Same predictors 
set significantly explained $29.4 \%$ variance of recognition $(\mathrm{F}(3.67)=9.305 ; \mathrm{p}=0.000)$. Emotional regulation and control singly explained $24 \%$ variance of recognition and emotional support seeking singly explained $8 \%$ variance of recognition. Predictors also significantly explained $30 \%$ variance of taking steps $(\mathrm{F}(3.67)=9.842 ; \mathrm{p}=0.000)$ with instrumental support seeking as only predictor that singly explained $12 \%$ variance of taking steps.

Furthermore, in fourth regression analysis, predictors significantly explained 11.3\% variance of taking steps $(\mathrm{F}(3.68)=2.895 ; \mathrm{p}$ $=0.041$ ), whereby positive experiences singly explained $7 \%$ variance of taking steps. Although satisfaction with life, positive and negative experiences did not significantly explained recognition, results suggest that recognition could be affected by negative experiences while ambivalence could be affected by positive experiences. Flourishing significantly explained only $13.7 \%$ variance of taking steps $(\mathrm{F}(1.69)=10.967 ; \mathrm{p}=0.001)$.

\section{Discussion and conclusion}

Marital status and type of hospitalization did not significantly explain any of criteria. Although marital status is an often used sociodemographic variable, its significance was confired by small number of studies that were focused on motivation for abstinence [28]. Insignificance of marital status in this study could be explained with quality of marital relationship, a variable that was not included in this study. Families whose members are alcohol addicts are more often affected by the negative impact of alcohol and maladaptive behavior that can decrease motivation for abstinence as well as the outcome of treatment.

Furthermore, insignificance of type of hospitalization could be explained with time period in which data was collected. Forced hospitalization could be more significant at the beginning of treatment when individuals did not yet get in touch with therapy program.

Variables of gender, age and education level significantly explained only recognition. Relatively small amount of explained variance could be due to a fact that only age displayed as a significant predictor. Analysis suggests that younger people show higher readiness to accept their own problems with alcohol and therefore have higher motivation to make a change. Results indicate that younger people understand the problem severity, that they adequately perceive consequences and damage that could face if they do not make a change. Accordingly, some studies suggest that older people could be in a phase of problem severity denial, which could cause them not to see negative consequences of alcohol in their daily functioning due to formed habits and attitudes [11]. This result is contrary to previous studies, according to which elderly people show higher total motivation for abstinence and therefore also higher recognition of problem [26,21,7]. Subjects' average age in this study was 49 years that could, according to some categorizations, be defined as a sample of predominantly older people. Some other authors have already warned that there are not universally defined age groups $[7,11]$. To sum up, this result could be also affected by gender, because other studies showed that older women have higher abstinece motivation [7].

This study shows that people with better control of negative emotions and those who use instrumental and emotional support seeking have higher ambivalence of feelings and more often take steps in making a change. It is also indicated that people with 
better control of negative emotions and frequent emotional support seeking, although with a rare instrumental support seeking have higher recognition, which means that individuals who learned how to regulate negative emotional states begin to question the necesity for change and become more open to accepting the change $[17,15]$. Absence of impulsiveness and negative expressiveness can lead to uncertainty in acceptability of addiction behavior and can be a trigger for accepting the change $[11,16]$. Results also suggest that motivation for abstinence in alcohol addicts can depend upon a change in emotional expression style [14-16]. Furthermore, higher recognition and ambivalence could be the reason for higher awareness of a fact that alcohol consumption cannot mask underlying emotions and that different coping styles for negative emotions are needed [11].

Significant contribution of coping strategies for taking steps could be explained by more importance of adaptive coping styles that include proactive behavior, which is consistent with previous studies [21]. Results indicate that people who frequently seek instrumental support have already made some changes in negative behavior, which is consistent with the results of Simoneau and Bergeron (2002).

Emotional support seeking and emotional regulation and control have been displayed as significant predictors of recognition. It is possible that people who do not seek emotional support have some difficulties in regulating negative emotions that stop them from recognizing the problem. They could still think of alcohol consumption as an answer to their problems $[15,22]$.

Moreover, results show that taking steps is predicted by life satisfaction, positive and negative emotions with positive emotions being the only significant predictor that is consistent with previous studies $[19,18,16]$. Due to a positive effect model, searching for positive resources leads to a frequent positive emotional state that can actively change negative behavior which is confirmed in this study. Growth of positive emotions and broad perspective of inpatients, which have been evaluated for the past 2 weeks, enables them to reevaluate choices that led to addiction [18]. Results can also be explained with therapy program that was active for 12 days at the time of data collection. It could be possible that inpatients have detected positive emotions as an answer to successfully finished aspects of therapy program. Given that more positive emotions are associated with longer staying in treatment and better outcomes, these results become clinically even more important [19]. Although satisfaction with life, positive and negative emotions did not significantly explain ambivalence, results indicate that higher positive experiences contribute to higher ambivalence that is consistent with other studies [16]. Similarly, results indicate that there is potential contribution of higher negative experiences to higher recognition that includes negative emotions as triggers for making decision about change. This direction of correlation was not found in other studies. Previous studies suggest that higher negative experiences predict lower recognition [16].

Furthermore, results indicate that flourishing significantly predicts only taking steps. Authors suggest that if beliefs become stronger after the treatment, there will also be an increase in positive emotions, meaning in life and behavioral actions in making the change [16]. It is possible that individuals who have bigger flourishing are more motivated for actual and visible change and that is consis- 
tent with previous studies [24,3]. Given that flourishing is a new variable that just started to be studied in alcohol addicts, more studies are needed. Considering the results of this study, the first hypothesis is partially disapproved while the second one is partially confirmed.

Motivation for abstinence is a construct that was used as a predictor variable in 90\% if studies that prognoses $77 \%$ of treatment outcome [26]. Therefore, it has become of great importance for clinical practice to identify those variables that could improve motivation which is the biggest benefit of this study. These results could stimulate the induction of new programs in clinical practice that could be focused on strengthening significant socioemotinal variables, such as interventions with focus on developing adequate emotional regulation and control, affective regulation training, emotional focused therapy, mindfulness therapy, dialectic behavioral therapy etc. Interventions specially designed for bracing or finding own meaning of life could be also useful. Furthermore, previous studies have been conducted at the begining or at the end of treatment, therefore this study tried to catch transition period in which motivation is not ostensibly increased as at the begining.

Disadvantages of this study are mostly related to a small and unrepresentative sample. Limitations can also be visible in the lack of control of inclusion criteria and not taking into account the number of previous hospitalizations, which can implicitly suggest that there were a great number of relapses, and therefore a low motivation for abstinence after the treatment's completion.

Future studies should use more inclusion criteria and control them better. It could be also interesting to use repeated measures in order to see possible change in motivation for abstinence from begging to end of treatment. Given that previous research have found gender differences in some predictors of motivation for abstinence, future studies could equalize sample and test that differences in socioemotional predictors used in this study.

In conclusion, motivation for abstinence in alcohol addicts is a complex process that has not been studied and understood yet. Obtained results showed that there are some socioemotinal predictors that are found to be significant predictors of motivation for abstinence which gives thus study clinical value. Although this study made a small step toward better understanding of motivation for abstinence, more studies are needed to illuminate these complex relationships.

\section{Acknowledgments}

None

\section{Conflict of interest}

None to declare

\section{References}

1. American Psychiatric Association. Diagnostic and Statistical Manual of Mental disorders - 5th ed. Washington: American Psychiatric Association; 2013.

2. World Health Organization. Global status report on alcohol and health. Geneva: WHO Press; 2011.

3. DeMarco NJ. Learned helplessness, spirituality, abstinence efficacy, and alcohol recovery (dissertation). Philadelphia College of Osteopathic Medicine; 2014.

Alcoholism and Psychiatry Research 2018;54:33-44 
4. Quintero JV. Demographic risk factors predicting substance use treatment outcomes (unpublished master), Graduate School of Western Carolina University; 2016.

5. Zhang Z, Friedmann PD, Gerstein DR. Does retention matter? Treatment duration and improvement in drug use. Addiction. 2003;98:673-84.

6. Stark M. Dropping out of substance abuse treatment: a clinically-oriented review. Clin Psychol Rev. 1992;12:93-116.

7. Laudet AB, Stanick V. Predictors of motivation for abstinence at the end ofoutpatient substance abuse treatment. J Subst Abuse Treat. 2010;38:317-27.

8. Simpson DD. Modeling treatment process and outcomes. Addiction. 2001;96:207-11.

9. Simoneau H, Bergeron J. Factors affecting motivation during the first six weeks of treatment. Addict Behav. 2002;28:1219-41.

10. Miller WR, Tonigan JS. Assessing drinkers' motivation for change: the stages of change readiness and treatment eagerness scale (SOCRATES). Psychol Addict Behav. 1996;10:81-9.

11. Slavinskienè J, Žardeckaitè-Matulaitienè K. Importance of alcohol-related expectations and emotional expressivity for prediction of motivation to refuse alcohol in alcohol-dependent patients. Medicina. 2014;50:169-74.

12. Laudet AB, Stanick V, Sands B. What could the program have done differently? A qualitative examination of reasons for leaving outpatient treatment. J Subst Abuse Treat. 2009;37:182-90.

13. Collins SE, Malone DK, Larimer ME. Motivation to change and treatment attendance as predictors of alcohol-use outcomes among project-based housing first residents. Addict Behav. 2012;37:931-9.

14. Fox HC, Hong KA, Sinha R. Difficulties in emotion regulation and impulse control in recently abstinent alcoholics compared with social drinkers. Addict Behav. 2008;33:388-94.

15. Berking M, Margraf M, Ebert D, Wupperman P, Hofmann SG, Junghanns K. Deficits in emotionregulation skills predict alcohol use during and after cognitive behavioral therapy for alcohol dependence. J Consult Clin Psychol. 2011;79:307-18.

16. Flora K, Stalikas A. Positive emotions and addiction. International Journal of Psychosocial Rehabilitation. 2015;19:57-85.
17. Cordovil de Sousa Uva M, Mikolajczak M, Luminet $\mathrm{O}$, Timary P, Cortesi M, de Blicquy PR, Luminet O. Moderating effect of emotional intelligence on the role of negative affect in the motivation to drink in alcohol-dependent subjects undergoing protracted withdrawal. Pers Indiv Differ. 2009;48:16-21.

18. Minami H, Yeh VM, Bold KW, Chapman GB, McCarthy DE. Relations among affect, abstinence motivation and confidence, and daily smoking lapse risk. Psychol Addict Behav. 2014;28:376-88.

19. Fredrickson BL. Cultivating positive emotions to optimize health and well-being. Prevention and Treatment. 2000;3:1-25.

20. Greenglass ER. (2002). Proactive coping. In Frydenberg UE, ed. Beyond coping: meeting goals, vision, and challenges. London: Oxford University Press; 2002. p. 37-62.

21. DiClemente CC, Doyle SR, Donovan D. Predicting treatment seekers' readiness to change their drinking behavior in the COMBINE study. Alcohol Clin Exp Res. 2009;33:879-92.

22. Sudraba V, Millere A, Deklava L, Millere E, Zumente Z, Circenic K, et. al. Stress coping strategies of drug and alcohol addicted patients in Latvia. Procedia Soc Behav Sci. 2015,205:632-6.

23. Donovan D, Mattison ME, Cisler RA, Longabaugh $\mathrm{R}$, Zweben A. Quality of life as an outcome measure in alcoholism treatment research. J Stud Alcohol Drugs. 2005;(Suppl 15):119-39.

24. Hart KE, Singh T. An existential model of flourishing subsequent to treatment for addiction: the importance of living a meaningful and spiritual life. Illn Crises Loss. 2009;17( Suppl 2):125-47.

25. McGaffin BJ, Deane FP, Kelly PJ, Ciarrochi J. Flourishing, languishing and moderate mental health: prevalence and change in mental health during recovery from drug and alcohol problems. Addict Res Theory. 2015;23(Suppl 5):351-60.

26. Adamson SJ, Sellman JD, Frampton CMA. Patient predictors of alcohol treatment outcome: a systematic review. J Subst Abus Treat. 2009;36:75-86.

27. Brezovec E. Consumption of alcohol in Croatian social reality: Alcohol as part of interaction ritual chain. Alcoholism and Psychiatry Research. 2017;53:139-47

28. Hiller ML, Narevic E, Webster J, Rosen P, Staton M, Leukefeld C, et al. Problem severity and moti- 
vation for treatment in incarcerated substance abusers. Subst Use Misuse. 2009;44(Suppl 1):28-41.

29. Takšić V. Skala emocionalne regulacije i kontrole (ERIK): provjera faktorske strukture. Psihologijske teme. 2003;12(Suppl 1):43-54.

30. Greenglass ER, Schwarzer R, Tauberts S. Tihe proactive coping inventory (PCI): a multidimensional research instrument (Internet). 1999. (cited 2017 may 12). Available from: http://userpage.fuberlin.de/ health/greenpci.htm

31. Diener E, Emmons RA, Larsen RJ, Griffin S. Tihe satisfaction with life scale. J Pers Assess. 1985;49(Suppl 1):71-5.
32. Diener E, Wirrtz D, Tov W, Prieto CK, Choi D, Oishi S, et al. New well-being measures: short scales to assess flourishing and positive and negative feelings. Soc Indic Res. 2009;97(Suppl 2):14356.

33. Komšo T, Burić I. Dienerove skale subjektivne dobrobiti: skala zadovoljstva životom, skala prosperiteta i skala pozitivnih i negativnih iskustava. In: Tucak Junaković I, ed. Zbirka psihologijskih skala i upitnika, 8. Odjel za psihologiju, Sveučilište u Zadru. 2016. p. 2-6.

\section{Socioemocionalni prediktori motivacije za apstinencijom kod ovisnika o alkoholu}

Sažetak - Motivacija za apstinencijom značajan je faktor u predviđanju uključenosti osoba ovisnih o alkoholu u tretman, njihovog zadržavanja na liječenju i ishoda tretmana te je dugo vremena bio zapostavljen. S obzirom na to da ovaj kompleksan proces još uvijek nije dovoljno istražen, u kliničkoj se praksi pojavila potreba za njegovim boljim razumijevanjem što bi moglo pomoći u terapijskom radu s ovisnicima. Cilj ovog istraživanja bio je identificirati socioemocionalne prediktore motivacije za apstinencijom kod osoba ovisnih o alkoholu koji su na liječenju minimalno 12 dana kako bi se zahvatio stvaran stupanj motivacije. U istraživanju su sudjelovale 72 osobe liječene na Odjelu za alkoholizam Psihijatrijske bolnice Sveti Ivan koje su dobrovoljno pristupile istraživanju. Motivacija za apstinencijom se ispitivala SOCRATES upitnikom, koji sa subskalama ambivalencije, rekognicije i poduzimanja koraka predstavlja kriterij. Kao potencijalni prediktori ispitane su demografske varijable, emocionalna regulacija i kontrola, suočavanje usmjerene na traženje instrumentalne i emocionalne podrške, zadovoljstvo životom, pozitivne i negativne emocije te prosperitet. Regresijska analiza pokazala je kako emocionalna regulacija i kontrola te suočavanje usmjereno na traženje instrumentalne i emocionalne podrške značajno objašnjuju 15,8\% ambivalencije, 29,4\% rekognicije i 30,6\% poduzimanja koraka, dok su zadovoljstvo životom te pozitivne i negativne emocije značajno objasnile 11,3\% poduzimanja koraka, a prosperitet $13,7 \%$ poduzimanja koraka. Od demografskih varijabli, spol, dob i stupanj obrazovanja objašnjavaju jedino 15,6\% rekognicije. Unatoč dobivenim rezultatima, ukupni postotci objašnjene varijance su relativno niski stoga bi istraživanje trebalo ponoviti na većem uzorku kako bi se omogućila generalizacija rezultata. Kliničke implikacije ovog istraživanja su značajne te uvelike doprinose unaprjeđenju bolničkih programa liječenja ovisnika o alkoholu.

Ključne riječi: motivacija, apstinencija, ovisnost, alkoholizam, emocije 